\title{
12. PREHNITE-PUMPELLYITE FACIES METAMORPHISM IN OCEANIC ARC BASEMENT FROM SITE 791 IN THE SUMISU RIFT, WESTERN PACIFIC ${ }^{1}$
}

\author{
Makoto Yuasa, ${ }^{2}$ Teruo Watanabe, ${ }^{3}$ Toshiaki Kuwajima, ${ }^{3}$ Tadao Hirama, ${ }^{4}$ and Kantaro Fujioka ${ }^{5}$
}

\begin{abstract}
Prehnite-pumpellyite facies metamorphism is described in the oceanic-arc basement rocks of Ocean Drilling Program Leg 126, Site 791 in the Sumisu Rift, western Pacific. Chemical variations of pumpellyite, epidote, chlorite, and prehnite are examined and paragenetic relations discussed. The metamorphism took place during the pre-rifting stage of an intraoceanic arc. During the backarc rifting stage, the geothermal gradient of the area was not as high as that of a spreading mid-oceanic ridge.
\end{abstract}

\section{INTRODUCTION}

Studies of the metamorphism of the oceanic crust have advanced since the International Phase of Ocean Drilling (IPOD) project. According to the summary by Maruyama and Liou (1988), diversity in ocean-floor metamorphism reflects a difference in tectonics. For example, the fast-spreading Pacific Ocean has higher geothermal gradients than the slow-spreading Atlantic; and prehnite-pumpellyite facies metamorphic rocks have not been collected from the Pacific Ocean floor, but they have been obtained from the Atlantic Ocean and Philippine Sea floors where the geothermal gradient is rather low (Maruyama and Liou, 1988).

We report here prehnite-pumpellyite facies rocks obtained from oceanic-arc basement on the eastern margin of the Philippine Sea. The sampling site is possibly an older arc basement that appears to have been metamorphosed before the commencement of backarc spreading. The rocks should offer thermal gradient data on the early stages of arc rifting.

\section{GEOLOGICAL SETTING OF THE SUMISU RIFT AND THE OHMACHI SEAMOUNT}

\section{Sumisu Rift}

The Izu-Bonin (Ogasawara) Arc is a set of north-trending ridges situated to the west of the Izu-Ogasawara (Bonin) Trench (Fig. 1). The Shichito-Iwojima Ridge delineates a volcanic front and forms a backbone of the arc.

A series of conspicuous topographic depressions in the backarc side of the Izu-Bonin Arc (backarc depressions) has been recognized (Tamaki et al., 1981; Fujioka, 1988). These depressions continue intermittently from southwest of Hachijojima to northwest of the Nishinoshima Islands. The Sumisu Rift is one of such typical depressions. Several scientific teams from Japan and the United States reached the conclusion from their geological and geophysical studies that the Sumisu Rift is an active intra-arc basin at the rifting stage, because active normal faults that are north-trending cut the surface sediment layers within the basin (Murakami, 1988). Volcanic rocks show a transitional nature from island-arc tholeiite to mid-ocean ridge basalt (MORB) (Ikeda and Yuasa, 1989). Site 791 of Ocean Drilling Program (ODP) Leg 126 is located at the center of the Sumisu Rift.

\footnotetext{
'Taylor, B., Fujioka, K., et al., 1992. Proc. ODP, Sci. Results, 126: College Station, TX (Ocean Drilling Program).

${ }^{2}$ Geological Survey of Japan, Tsukuba, Ibaraki 305, Japan.

${ }^{3}$ Department of Geology and Mineralogy, Hokkaido University, Sapporo 060, Japan.

${ }^{4}$ Department of General Education, Hokkaido University, Sapporo 060, Japan.

${ }^{5}$ Ocean Research Institute, University of Tokyo, 1-15-1 Minamidai, Nakano, Tokyo 164, Japan (present address: Japan Marine Science and Technology Center, 2-14 Natsushima, Yokosuka, Kanagowa 238, Japan).
}

The drill hole penetrated about $1100 \mathrm{~m}$ below the seafloor ( $\mathrm{mbsf}$ ) into basaltic basement (Shipboard Scientific Party, 1990).

\section{Forearc "Ohmachi" Seamount}

The Nishinoshima Trough has a rift morphology and obliquely cuts across the Izu-Bonin Arc between the Sofugan and Nishinoshima islands (Fig. 1). The distance between the nearest islands is widest at about $290 \mathrm{~km}$ here at the Shichito-Iwojima Ridge. There are nine large seamounts, some of which have parasitic highs, between the Sofugan and Nishinoshima islands. Of these, seven conical and subconical groups of seamounts are distributed linearly along the Shichito-Iwojima Ridge. Two other large seamounts occur on the outer and inner sides of the ridge (Fig. 1). The seven seamounts have been collectively named the Shichiyo (Seven Days) seamounts, and two other large elongated ones at the northeast and southwest parts have been named the Ohmachi and Sawa seamounts, respectively. The Shichiyo seamounts (i.e., Nichiyo [Sunday] to Doyo [Saturday] seamounts from north to south) are distributed on the volcanic front, whereas the Ohmachi and Sawa seamounts are situated off the axis of the front.

The Ohmachi Seamount was regarded as an old seamount (Paleogene to early Miocene) in the marine geologic map of the area by Honza et al. (1982) on the basis of a seismic profile analysis. The top of the seamount is flat (not conical), and its origin is not regarded as a submarine volcanic edifice. On the seismic profiles, thick folded and faulted sediments mantle the seamount. Additional evidence supports the interpretation that it is not a young submarine volcano but an older seamount with a complex development history. Recently, Yuasa et al. (1988) sampled volcanic and sedimentary rocks from the seamount and dated two hypersthene-augite andesite samples at about 32-33 Ma. The Shikoku and Parece Vela basins began to open at about 25 (Shih, 1980) and 30 Ma (Mrozowski and Hayes, 1979), respectively.

The volcanic rocks of the seamount may represent those of the proto-Izu-Mariana Ridge that was not separated from the Kyushu-Palau Ridge. The west side of the seamount was cut by a fault scarp, and weakly metamorphosed volcanic rocks were obtained from the lower part of the scarp (D794 [dredge site number of GSJ], $29^{\circ} 04.54 \mathrm{~N}, 140^{\circ} 43.88 \mathrm{E}$, depth $3115 \mathrm{~m}$ ), whereas the dated andesites are rather fresh and were dredged from half-way up on the flank of the seamount (D731 [dredge site number of GSJ], $29^{\circ} 09.04{ }^{\circ} \mathrm{N}, 140^{\circ} 42.76^{\prime} \mathrm{E}$, depth $2645 \mathrm{~m}$ ). Thus, we infer that the fault scarp was formed at the beginning of the opening of the Parece Vela Basin, and the metamorphism occurred before the above-mentioned andesitic volcanism.

\section{Petrography}

Metamorphic rocks described here came from the lowermost part of the core of Site 791 in the Sumisu Rift as well as from a dredge 


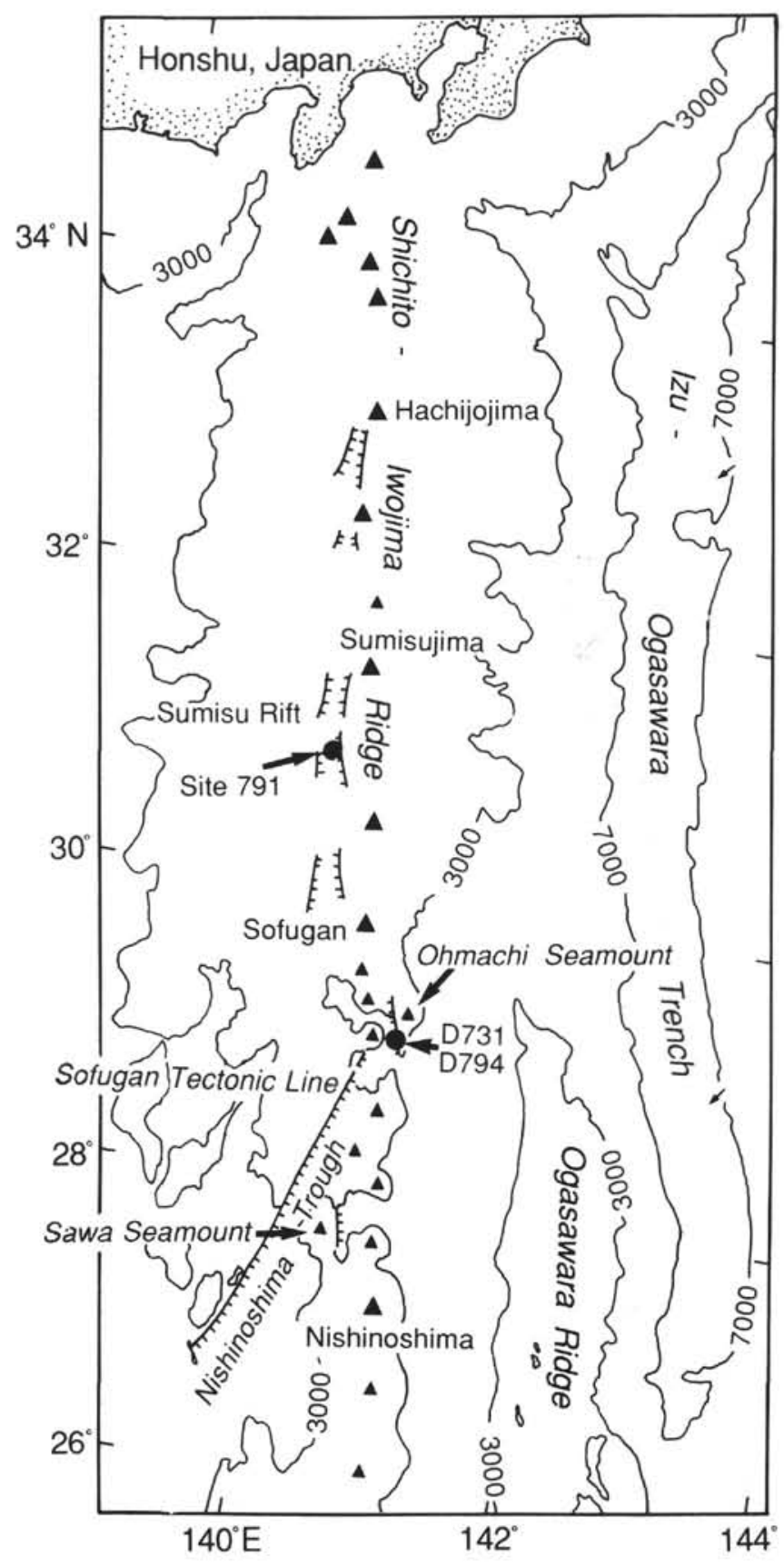

Figure 1. Locality of sampling sites in the Sumisu Rift and the Ohmachi Seamount. Contours of 3000 and $7000 \mathrm{~m}$ are shown. Large solid triangles show Quaternary volcanic islands, and small ones show seamounts on the ShichitoIwojima Ridge. D731 and D794 show the dredge site numbers (see text).

haul taken from the fault scarp of the Ohmachi Seamount at the central part of the Izu-Bonin Arc.

\section{Sample 126-791B-79R-1, Piece 11, from Sumisu Rift}

Pumpellyite occurs only in one single thin section among the 12 samples we collected from Hole 791B. The pumpellyite-bearing rock is a crystal-lithic tuff with white spots in a dark bluish green matrix. The white spots are albitized plagioclase $\left(\mathrm{An}_{4 \%}-\mathrm{An}_{\sim 12 \%}\right)$ together with small amounts of white mica and rare epidote. Apart from the plagioclase, no other primary igneous minerals were recognized.
Flattened pumice fragments are the dominant lithic material and are replaced by an intergrowth of chlorite and smectite (Shipboard Scientific Party, 1990). Some porous volcanic rock fragments are also present. No primary mafic minerals have survived, and the rock pores are filled with pumpellyite with albite, and occasionally with chlorite and rare pyrite. The matrix of the tuff is recrystallized to the metamorphic assemblage quartz, chlorite, titanite, and epidote.

Pumpellyite occurs as irregular monomineralic aggregates of fanshaped fibrous crystals filling spaces between the crystals of relic plagioclase and rock fragments, within the matrix, or filling amygdules. Pleochroism is weak $\left(\mathrm{X}^{\prime}=\right.$ pale brown and $\mathrm{Z}^{\prime}=$ pale green $)$. Pumpellyite crystals have a dusty appearance in thin section. Less commonly, pumpellyite is found replacing plagioclase crystals.

Small amounts of epidote were found in the marginal parts of pumpellyite aggregates. When it coexists with felsic minerals, it is associated with chlorite.

The mode of occurrence of chlorite is similar to that of pumpellyite: that is, filling spaces between the fragments of crystals and rocks, and in the pores of rock fragments. In addition, chlorite commonly replaces flattened pumice fragments.

Other secondary minerals include albite, quartz, calcite, titanite, and pyrite. Albite replaces plagioclase laths in the groundmass of rock fragments; it also occurs as a cavity filler with pumpellyite. Potassium feldspar may replace primary igneous plagioclase laths in the rock fragments. No zeolite is present.

Common metamorphic mineral associations in the rocks are as follows: pumpellyite + albite + chlorite, pumpellyite + albite + epidote \pm chlorite, and epidote + chlorite + albite. Pumpellyite + albite + chlorite were commonly observed as irregular-shaped aggregates in the matrix and as amygdule-filling minerals. Epidote rarely accompanies the last assemblage. Pumpellyite + epidote generally replace plagioclase.

\section{D794-7 and -8 from Ohmachi Seamount}

The rocks were dredged from a fault scarp west of the Ohmachi Seamount near Sofugan island. The position is at the northeastern edge of the Nishinoshima Trough, which crosses the Izu-Bonin Arc obliquely in its central part and divides it into northern and southern parts. The westernmost edge of the trough is cut by the Sofugan Tectonic Line (Yuasa, 1985). The metamorphic rocks are pale-green, fist-sized blocks partly covered with a dark reddish brown film. A slickensided surface was often observed on the blocks.

Sample D794-7 is a volcanic breccia that consists of fragments with an andesitic texture. The primary pyroxene phenocrysts are completely replaced by chlorite, clay minerals, and rare pumpellyite. The albitized plagioclase phenocrysts are partly replaced by pumpellyite. The pore of the rubble is filled by pumpellyite, albite, and chlorite. The breccia matrix has recrystallized to an albite, quartz, epidote, calcite, and titanite assemblage. Veins of prehnite, albite, and analcime occur.

Sample D794-8 is also a volcanic breccia, but olivine pseudomorphs replaced by chlorite occur as phenocrysts in addition to altered pyroxene phenocrysts in the rubble. Vein minerals are albite, quartz, calcite, and analcime. Other features are the same as Sample D794-7.

In most cases, pumpellyite replaces plagioclase phenocrysts and microlites, and also occurs as aggregates together with albite-filling amygdules and pores of the rock fragments. It occurs rarely in the matrix of the rock as disseminated crystals. Strong pleochroism is observed in pumpellyite replacing plagioclase $\left(\mathrm{X}^{\prime}=\right.$ yellow and $\mathrm{Z}^{\prime}=$ colorless). However, coarse, rodlike crystals of pumpellyite-filling amygdules have weak pleochroism. Pumpellyite in the pores of the rock fragments is fine-grained and brownish yellow and has very weak pleochroism. Pumpellyite from the seamount occurs as clear crystals and can be distinguished individually in contrast to pumpellyite from the Sumisu Rift.

Prehnite occurs as acicular or flaky crystals filling large pores and is accompanied by metamorphic quartz, albite, and chlorite. Epidote 
replaces plagioclase phenocrysts and it typically coexists with pumpellyite. In the matrix of the rock, epidote coexists with chlorite, quartz, albite, and titanite. Chlorite often occurs with pumpellyite, but chlorite alone fills pores and replaces primary mafic phenocrysts.

The common mineral assemblages in the rocks from the Ohmachi Seamount are as follows: pumpellyite + albite + epidote, pumpellyite + albite + chlorite, pumpellyite + albite + epidote + titanite, and pumpellyite + albite + epidote + chlorite. Pumpellyite + albite + epidote and pumpellyite + albite + chlorite assemblages are common and were observed in all modes of occurrence described above. However, titanite accompanies the pumpellyite + epidote assemblage only in replaced plagioclase. Chlorite accompanies the assemblage when it replaces relic olivine and pyroxene phenocrysts.

\section{MINERAL CHEMISTRY}

Pumpellyite, epidote, chlorite, and prehnite were analyzed by an automated JEOL (Model XMA 733) microprobe at $15 \mathrm{kV}$ and a probe current of $20 \mathrm{nA}$ according to a method described by Okumura and Soya (1976) using the Bence and Albee (1968) correction method.

\section{Pumpellyite}

Pumpellyite is a common constituent in the three rocks studied. Representative chemical compositions are listed in Table 1, and all the available data are plotted in Figures 2 and 3.

The chemical compositions of pumpellyite from the Ohmachi Seamount (solid squares) range from $\mathrm{Al}$-rich, $\mathrm{Fe}$-poor to $\mathrm{Al}$-poor, $\mathrm{Fe}$-rich on the $\mathrm{Al}_{2} \mathrm{O}_{3}-\mathrm{Fe}_{2} \mathrm{O}_{3}$ diagram (Fig. 2). Pumpellyite from the Sumisu Rift sample (open squares) has limited compositional variation restricted to the less aluminous field of the Ohmachi Seamount pumpellyite. Pumpellyite from both samples of the Izu-Bonin Arc plot among the low aluminous field of pumpellyite from zeolite facies rocks in the Kamuikotan Zone, Japan (Ishizuka, 1991); the higher aluminous field of pumpellyite from pumpellyite-actinolite facies rocks from Loeche, Switzerland (Coombs et al, 1976); and in a similar field for pumpellyite from prehnite-pumpellyite facies rocks from the Vema Fracture Zone (Mevel, 1981) (Fig. 2). The field for the Al-rich member from the seamount overlaps with that of the higher grade metamorphic pumpellyites.

The chemical compositions of pumpellyite vary greatly within a single section, but they can be used for a comparison of the metamorphic grade of the rocks if we take their mode of occurrence into account (Ishizuka, 1991). The compositional variation of pumpellyite with its mode of occurrence is also shown in the $\mathrm{Al}-\mathrm{Fe}-\mathrm{Mg}$ diagram (Fig. 3). Some amygdules and pore-filling pumpellyite show lower Al ratios than those of the other modes of occurrences (Fig. 3). Pumpellyite from zeolite (Kamuikotan, circle), prehnite-pumpellyite (Vema, open diamond), and pumpellyite-actinolite (Loeche, solid triangle) facies are also plotted in Figure 3. Some of the iron-rich member from the Izu-Bonin Arc is comparatively iron-rich and overlaps with zeolite facies pumpellyites, although pumpellyite from wairakite-bearing rocks is much more iron-rich.

\section{Epidote}

Epidote is pistacitic with $\mathrm{Fe}^{3+}$ in the $\mathrm{Y}$-site ranging from 0.7 to near 1.0 (Table 2). Chemical compositions of epidote from both sites are similar to each other, but those from the Ohmachi Seamount tend to be slightly richer in $\mathrm{Al}$ (Fig. 4). Epidote is compositionally heterogeneous; rims have a weak pleochroism and are poorer in iron than cores that have strong pleochroism and higher birefringence.

\section{Chlorite}

Chlorite compositions are plotted in Figure 5 in terms of $\mathrm{FeO}_{\sqrt{ }} / \mathrm{FeO}_{\mathrm{t}}$ $+\mathrm{MgO})$ vs. $\mathrm{SiO}_{2}$ and representative analyses are listed in Table 3 . Chlorites from the Sumisu Rift show variable $\mathrm{SiO}_{2}$ contents from about $28 \%$ to $33 \%$, whereas $\mathrm{FeO}_{\mathrm{r}} /\left(\mathrm{FeO}_{\mathrm{t}}+\mathrm{MgO}\right)$ ratios stay almost constant. Pore-filling chlorite tends to be poorer in $\mathrm{SiO}_{2}$, and pumice replacement chlorite is richer in $\mathrm{SiO}_{2}$ and $\mathrm{MgO}$. Chlorites from the Ohmachi Seamount plot in a restricted area and have lower $\mathrm{SiO}_{2}$ and higher $\mathrm{FeO}$ in comparison with those from the Sumisu Rift.

Chlorites from these sites are plotted near the compositional fields of those of the zeolite-facies rocks of Vancouver Island (Cho et al., 1986) and the prehnite-pumpellyite facies rocks from the Vema

Table 1. Representative chemical compositions of pumpellyite from the Ohmachi Seamount (1-5) and Sumisu Rift (6-9).

\begin{tabular}{|c|c|c|c|c|c|c|c|c|c|}
\hline & \multicolumn{5}{|c|}{ Ohmachi Seamount } & \multicolumn{4}{|c|}{ Sumisu Rift } \\
\hline & 1 & 2 & 3 & 4 & 5 & 6 & 7 & 8 & 9 \\
\hline Occurrence & $\begin{array}{l}\text { Pore } \\
\text { filling }\end{array}$ & $\begin{array}{l}\text { Amygdule } \\
\text { filling }\end{array}$ & $\begin{array}{l}\text { Plagioclase } \\
\text { micro- } \\
\text { phenocryst }\end{array}$ & $\begin{array}{l}\text { Plagioclase } \\
\text { phenocryst }\end{array}$ & Matrix & $\begin{array}{l}\text { Pore } \\
\text { filling }\end{array}$ & $\begin{array}{c}\text { Pore } \\
\text { filling }\end{array}$ & Matrix & Matrix \\
\hline $\mathrm{SiO}_{2}$ & 35.42 & 35.99 & 36.92 & 37.07 & 37.52 & 36.55 & 36.28 & 36.83 & 37.03 \\
\hline $\mathrm{TiO}_{2}$ & 0.15 & 0.09 & 0.19 & 0 & 0.09 & 0.18 & 0.22 & 0 & 0 \\
\hline $\mathrm{Al}_{2} \mathrm{O}_{3}$ & 18.94 & 19.36 & 21.47 & 24.16 & 25.83 & 17.66 & 19.30 & 20.90 & 22.22 \\
\hline $\mathrm{Fe}_{2} \mathrm{O}_{3}$ & 13.75 & 14.09 & 9.99 & 7.16 & 4.27 & 14.99 & 13.11 & 10.89 & 9.18 \\
\hline $\mathrm{MnO}$ & 0.08 & 0.09 & 0.22 & 0.21 & 0.17 & 0.18 & 0.12 & 0.12 & 0.15 \\
\hline $\mathrm{MgO}$ & 1.97 & 1.70 & 1.84 & 2.06 & 2.99 & 2.17 & 2.11 & 2.27 & 2.40 \\
\hline $\mathrm{CaO}$ & 21.51 & 21.66 & 22.35 & 22.71 & 22.98 & 21.93 & 21.78 & 21.63 & 22.41 \\
\hline $\mathrm{Na}_{2} \mathrm{O}$ & 0.02 & 0.02 & 0.02 & 0.02 & 0.02 & 0.04 & 0.03 & 0.01 & 0.00 \\
\hline $\mathrm{K}_{2} \mathrm{O}$ & 0.02 & 0 & 0 & 0 & 0.03 & 0.01 & 0 & 0 & 0.02 \\
\hline Total & 91.86 & 93.00 & 93.00 & 93.39 & 93.90 & 93.71 & 92.95 & 92.65 & 93.41 \\
\hline $\mathrm{Si}$ & 5.937 & 5.954 & 6.020 & 5.954 & 5.933 & 6.032 & 5.988 & 6.032 & 5.991 \\
\hline Al IV & 0.063 & 0.046 & & 0.046 & 0.067 & & 0.012 & & 0.009 \\
\hline Al VI & 3.680 & 3.730 & 4.127 & 4.528 & 4.748 & 3.436 & 3.744 & 4.036 & 4.228 \\
\hline $\mathrm{Ti}_{2}$ & 0.019 & 0.011 & 0.023 & 0 & 0.011 & 0.022 & 0.027 & & 0 \\
\hline $\mathrm{Fe}^{3+}$ & 1.734 & 1.754 & 1.226 & 0.865 & 0.508 & 1.862 & 1.628 & 1.342 & 1.118 \\
\hline Mn & 0.011 & 0.013 & 0.030 & 0.029 & 0.023 & 0.025 & 0.017 & 0.017 & 0.021 \\
\hline $\mathrm{Mg}$ & 0.492 & 0.419 & 0.447 & 0.493 & 0.705 & 0.534 & 0.519 & 0.554 & 0.579 \\
\hline $\mathrm{Ca}$ & 3.863 & 3.840 & 3.905 & 3.908 & 3.894 & 3.878 & 3.852 & 3.796 & 3.885 \\
\hline $\mathrm{Na}$ & 0.007 & 0.006 & 0.006 & 0.006 & 0.006 & 0.013 & 0.010 & 0.003 & 0 \\
\hline $\mathrm{K}$ & 0.004 & 0 & 0 & 0 & 0.006 & 0.002 & 0 & 0 & 0.004 \\
\hline Total & 15.811 & 15.773 & 15.784 & 15.829 & 15.900 & 15.804 & 15.796 & 15.780 & 15.834 \\
\hline
\end{tabular}

Notes: 1 = D794-7, pore filling; 2 = D794-7, amygdule filling; 3 = D794-8, replacement of plagioclase microlite; $4=$ D794-7, replacement of plagioclase phenocryst; $5=$ D794-7, dispersed crystal matrix; 6 and $7=$ pore filling; 8 and 9 $=$ aggregate between crystals and rock fragments in matrix. 


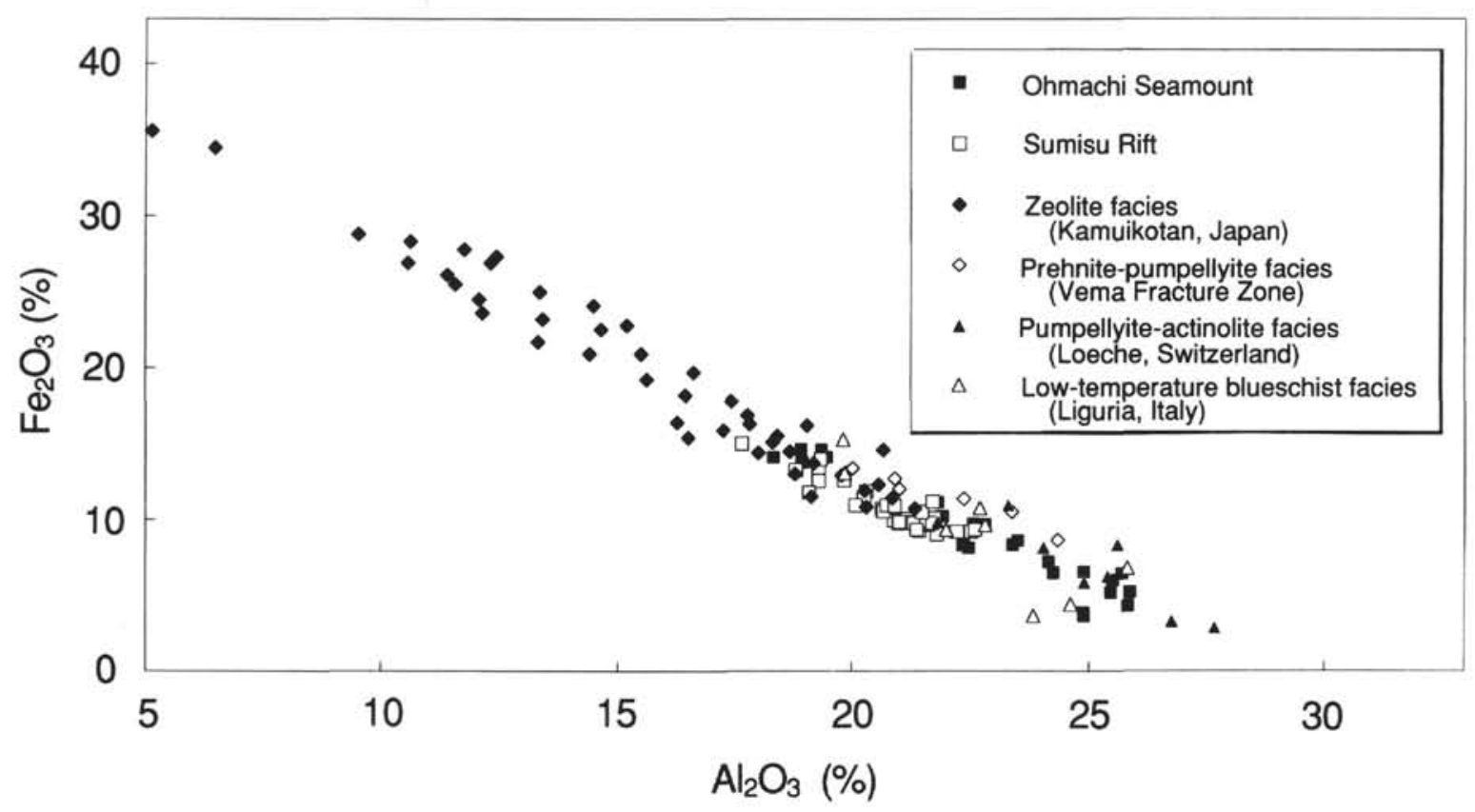

Figure 2. $\mathrm{Fe}_{2} \mathrm{O}_{3}$ vs. $\mathrm{Al}_{2} \mathrm{O}_{3}$ diagram for pumpellyites from the Sumisu Rift and Ohmachi Seamount as well as data from other metamorphic terrains. References to chemical compositions are as follows: Kamuikotan Zone, Japan (Ishizuka, 1991); Vema Fracture Zone (Mevel, 1981); Loeche, Switzerland (Coombs et al., 1976); and Liguria, Italy (Lucchetti et al., 1990).

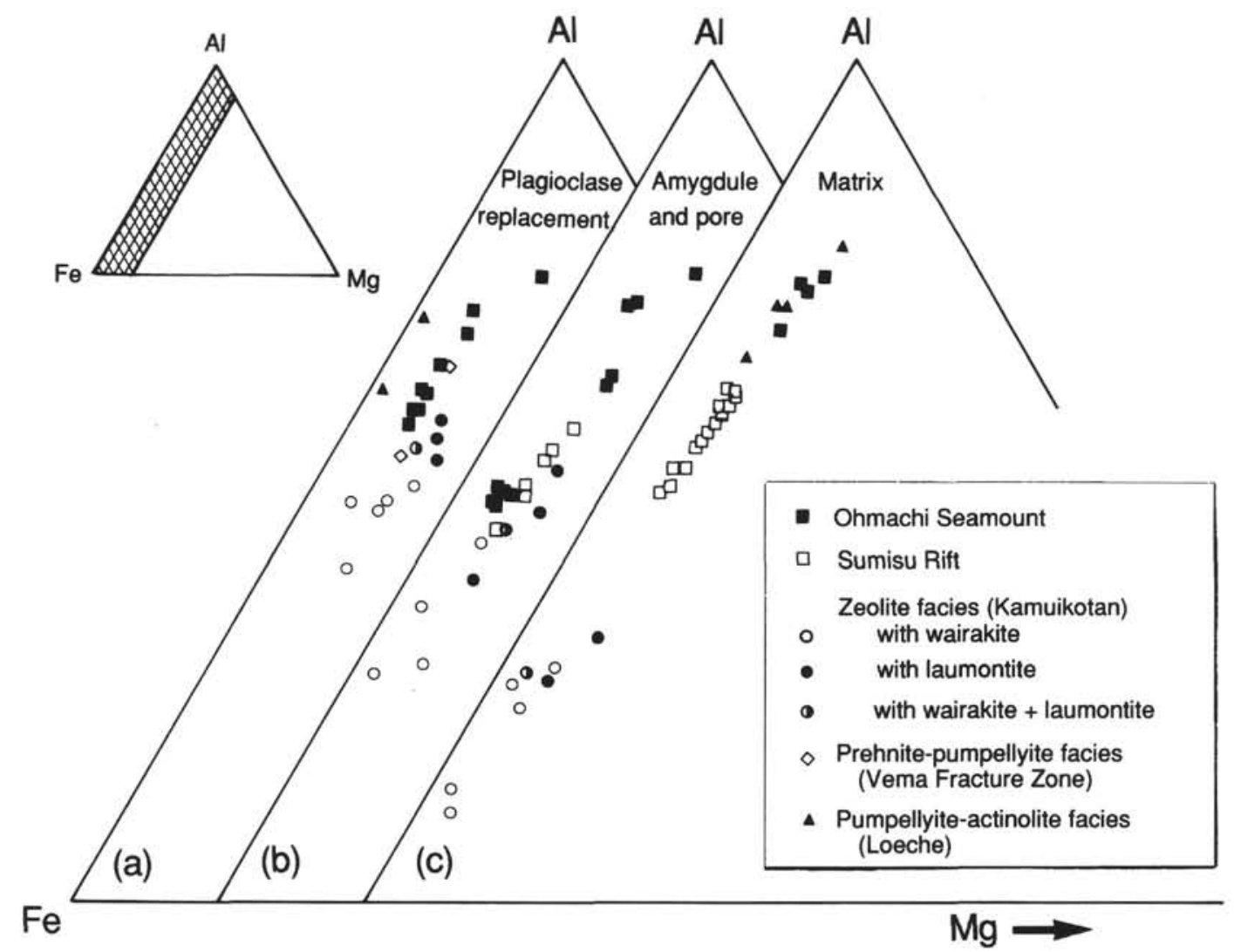

Figure 3. Al-Fe-Mg diagrams of pumpellyites with mode of occurrences. References are as follows: Kamuikotan Zone, Japan (Ishizuka, 1991); Vema Fracture Zone (Mevel, 1981); and Loeche, Switzerland (Coombs et al., 1976). 
Table 2. Representative chemical compositions of epidote from the Ohmachi Seamount (1-2) and Sumisu Rift (3-5).

\begin{tabular}{|c|c|c|c|c|c|}
\hline & \multicolumn{2}{|c|}{ Ohmachi Seamount } & \multicolumn{3}{|c|}{ Sumisu Rift } \\
\hline & 1 & 2 & 3 & 4 & 5 \\
\hline Occurrence & Matrix & $\begin{array}{l}\text { Plagioclase } \\
\text { replacement }\end{array}$ & $\begin{array}{c}\text { Matrix } \\
\text { with } \\
\text { chlorite }\end{array}$ & $\begin{array}{c}\text { Matrix } \\
\text { with } \\
\text { pumpellyite }\end{array}$ & $\begin{array}{c}\text { Matrix } \\
\text { with } \\
\text { albite }\end{array}$ \\
\hline $\mathrm{SiO}_{2}$ & 37.07 & 37.49 & 37.40 & 37.65 & 38.40 \\
\hline $\mathrm{TiO}_{2}$ & 0.13 & 0.91 & 0.25 & 0.23 & 0.18 \\
\hline $\mathrm{Al}_{2} \mathrm{O}_{3}$ & 23.70 & 20.81 & 20.53 & 22.22 & 24.53 \\
\hline $\mathrm{Fe}_{2} \mathrm{O}_{3}$ & 13.01 & 15.00 & 16.00 & 13.79 & 12.04 \\
\hline $\mathrm{MnO}$ & 0.16 & 0.08 & 0.09 & 0.10 & 0.25 \\
\hline $\mathrm{MgO}$ & 0.42 & 0 & 0 & 0 & 0 \\
\hline $\mathrm{CaO}$ & 21.32 & 22.96 & 23.05 & 22.55 & 22.91 \\
\hline $\mathrm{Na}_{2} \mathrm{O}$ & 0 & 0 & 0.01 & 0 & 0.03 \\
\hline $\mathrm{K}_{2} \mathrm{O}$ & 0.02 & 0.01 & 0 & 0.01 & 0 \\
\hline Total & 95.83 & 97.26 & 97.33 & 96.55 & 98.34 \\
\hline $\mathrm{Si}$ & 2.998 & 3.028 & 3.029 & 3.041 & 3.022 \\
\hline Al IV & 0.002 & & 0 & & \\
\hline $\mathrm{Al}$ VI & 2.258 & 1.982 & 1.960 & 2.116 & 2.276 \\
\hline & 0.008 & 0.055 & 0.015 & 0.014 & 0.011 \\
\hline $\mathrm{Fe}^{3+}$ & 0.792 & 0.912 & 0.975 & 0.838 & 0.713 \\
\hline Mn & 0.011 & 0.005 & 0.006 & 0.007 & 0.017 \\
\hline $\mathrm{Mg}$ & 0.051 & & & 0 & 0 \\
\hline $\mathrm{Ca}$ & 1.848 & 1.987 & 2.000 & 1.952 & 1.932 \\
\hline $\mathrm{Na}$ & & & 0.002 & & 0.005 \\
\hline $\mathrm{K}$ & 0.002 & 0.001 & & 0.001 & 0 \\
\hline Total & 7.970 & 7.970 & 7.987 & 7.969 & 7.976 \\
\hline
\end{tabular}

Notes: $1=$ D794-7, in matrix; 2 = D794-8, replacement of plagioclase; $3=$ accompanying with chlorite; $5=$ accompanying with pumpellyite; $6=$ accompanying with albite.

Fracture Zone (Mevel, 1981). However, they have less $\mathrm{FeO}$ and more $\mathrm{SiO}_{2}$ than chlorite from pumpellyite-actinolite facies (Loeche, Switzerland; Coombs et al., 1976) and blueschist facies (Liguria, Italy; Lucchetti et al., 1990) rocks (Fig. 5).

\section{Prehnite}

Prehnite does not occur in the Sumisu Rift sample. Prehnite from the Ohmachi Seamount tends to be rich in iron at 4-5 wt\% (Table 4). The prehnites plot in the overlapping part of the zeolite facies rocks from
Vancouver Island (Cho et al, 1986) and those of prehnite-pumpellyite facies rocks of the Vema Fracture Zone (Mevel, 1981) (Fig. 6).

\section{DISCUSSION \\ Metamorphic Facies}

The metamorphic rocks collected from the Ohmachi Seamount and Sumisu Rift are both characterized by the pumpellyite, chlorite, albite assemblage and lack actinolite, indicating that they were affected by lower grade metamorphism than that of the pumpellyiteactinolite facies. Prehnite occurs in the Ohmachi Seamount samples, but it does not coexist together with pumpellyite. Analcime veins also occur in the Ohmachi Seamount rocks. No prehnite or zeolite are found in the Sumisu Rift sample.

The chemical compositions of pumpellyites have been used as indicators of metamorphic grade by many authors (Coombs et al., 1976; Kawachi, 1975; Mevel, 1981); that is, Fe-rich pumpellyite forms at a lower temperature, whereas more Al-rich pumpellyite occurs in higher grade rocks. As mentioned earlier, the composition of pumpellyite from the Izu-Bonin Arc plots near the field of prehnitepumpellyite facies pumpellyite rather than near that of the zeolite facies rocks (Fig. 2). In Figure 3, although they overlap the more aluminous part of the field of pumpellyite from the wairakite zone of zeolite facies (Ishizuka, 1991). This indicates that the metamorphic conditions were those of prehnite-pumpellyite facies grade. Pumpellyite from the Sumisu Rift tends to be richer in Fe than that from the Ohmachi Seamount, but the compositional overlap is restricted to the field of pumpellyite from wairakite zone rocks. These pumpellyites are clearly distinguished from the laumontite-zone pumpellyites on the basis of their lower iron contents. As these iron-poor pumpellyites coexist with albite, they may have formed by a reaction between laumontite and iron-rich pumpellyite.

The analcime veins of the Ohmachi Seamount rocks may have originated from local undersaturation of $\mathrm{SiO}_{2}$ in a later stage.

\section{Origin of the Metamorphism}

The crystal-lithic tuff of Sample 126-791B-79R-1, Piece 11, itself has not been analyzed; however, another piece from the near-core position

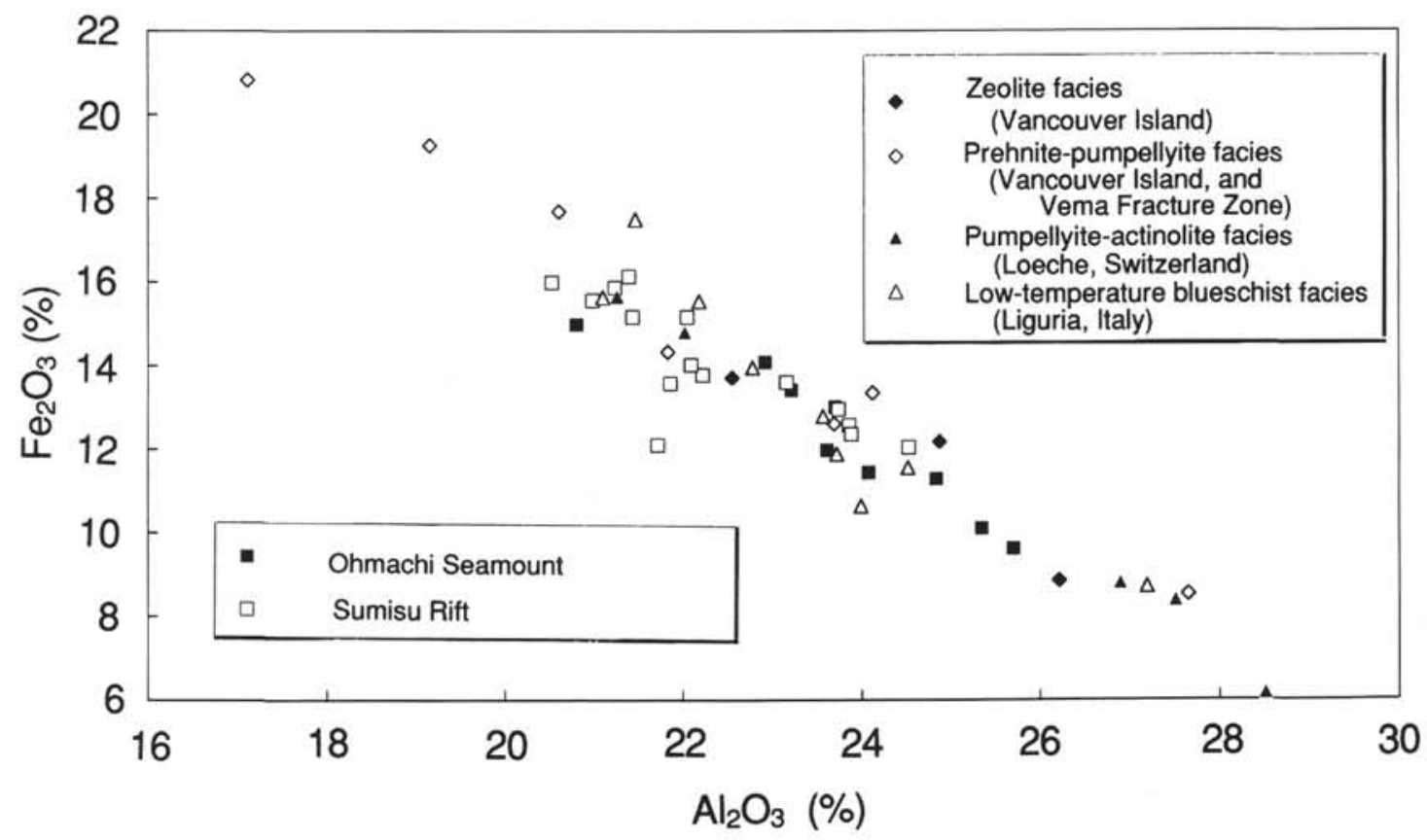

Figure 4. $\mathrm{Fe}_{2} \mathrm{O}_{3}$ vs. $\mathrm{Al}_{2} \mathrm{O}_{3}$ diagram of epidotes from the Sumisu Rift (open square) and the Ohmachi Seamount (solid square) rocks. References to chemical compositions are as follows: Vancouver Island (Cho et al., 1986); Vema Fracture Zone (Mevel, 1981); Loeche, Switzerland (Coombs et al., 1976); and Liguria, Italy (Lucchetti et al., 1990). 


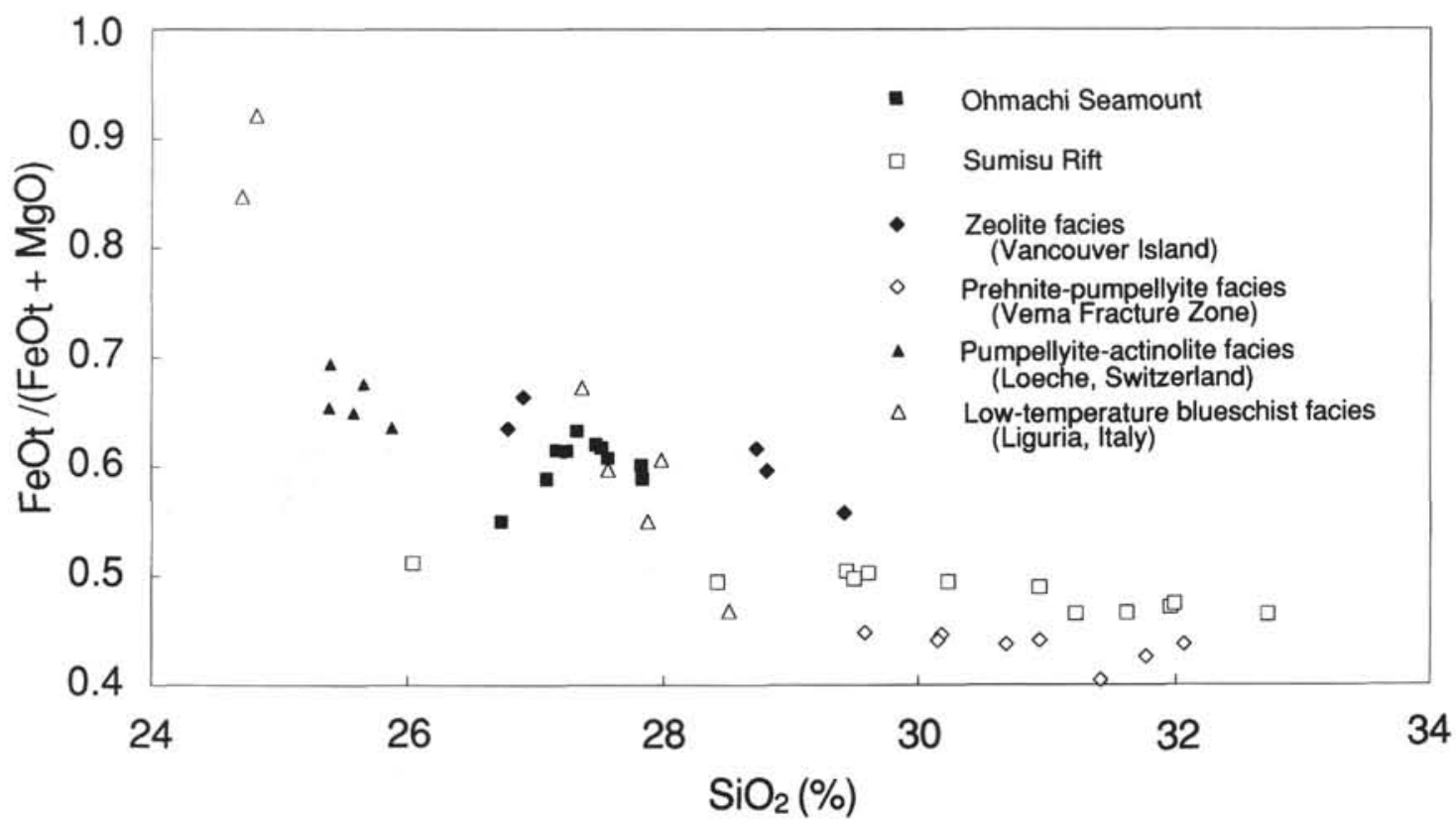

Figure 5. $\mathrm{FeO}_{\mathrm{l}} /\left(\mathrm{FeO}_{\mathrm{t}}+\mathrm{MgO}\right)$ vs. $\mathrm{SiO}_{2}$ diagram of chlorite from the Sumisu Rift and Ohmachi Seamount compared with data from other metamorphic areas. References are the same as in Figure 4.

of the same lithology and belonging to the same unit (Unit 28) was analyzed and described in the Initial Reports (Shipboard Scientific Party, 1990). According to their description, although the Unit 28 rocks are strongly altered, the alteration-resistant discriminant elements, Ti, V, $\mathrm{Zr}$, Y, suggest an island-arc origin. As these rocks are overlain by or intercalated with syn-rift basalt, it is suggested that the tuff constituted part of the island-arc basement before rifting occurred.

On the other hand, two kinds of volcanic rocks were obtained from the Ohmachi Seamount mentioned earlier. One was a nonmetamor-

Table 3. Representative chemical compositions of chlorite from the Ohmachi Seamount (1-3) and Sumisu Rift (4-5).

\begin{tabular}{|c|c|c|c|c|c|}
\hline & \multicolumn{3}{|c|}{ Ohmachi Seamount } & \multicolumn{2}{|c|}{ Sumisu Rift } \\
\hline & 1 & 2 & 3 & 4 & 5 \\
\hline Occurrence & $\begin{array}{c}\text { Matrix } \\
\text { with } \\
\text { pumpellyite }\end{array}$ & $\begin{array}{c}\text { Mafic } \\
\text { microlite } \\
\text { replacement }\end{array}$ & $\begin{array}{l}\text { Plagioclase } \\
\text { replacement } \\
\text { with } \\
\text { pumpellyite }\end{array}$ & $\begin{array}{l}\text { Pore } \\
\text { filling }\end{array}$ & $\begin{array}{l}\text { Pumice } \\
\text { replacement }\end{array}$ \\
\hline $\mathrm{SiO}_{2}$ & 26.73 & 27.82 & 27.32 & 28.46 & 31.62 \\
\hline $\mathrm{TiO}_{2}$ & 0.17 & 0 & 0 & 0.05 & 0.25 \\
\hline $\mathrm{Al}_{2} \mathrm{O}_{3}$ & 20.18 & 18.33 & 17.96 & 18.47 & 17.68 \\
\hline $\mathrm{FeO}$ & 21.93 & 24.71 & 25.79 & 19.73 & 18.02 \\
\hline $\mathrm{MnO}$ & 0.53 & 0.53 & 0.53 & 0.48 & 0.40 \\
\hline $\mathrm{MgO}$ & 17.97 & 16.42 & 15.01 & 20.18 & 20.65 \\
\hline $\mathrm{CaO}$ & 0.04 & 0.10 & 0.18 & 0.10 & 0.43 \\
\hline $\mathrm{Na}_{2} \mathrm{O}$ & 0.02 & 0.06 & 0.02 & 0.03 & 0.06 \\
\hline $\mathrm{K}_{2} \mathrm{O}$ & 0 & 0.06 & 0.04 & 0.01 & 0.09 \\
\hline Total & 87.57 & 88.03 & 86.85 & 87.51 & 89.20 \\
\hline $\mathrm{Si}$ & 5.543 & 5.820 & 5.838 & 5.826 & 6.251 \\
\hline Al IV & 2.457 & 2.180 & 2.162 & 2.174 & 1.749 \\
\hline Al VI & 2.476 & 2.341 & 2.363 & 2.283 & 2.371 \\
\hline $\mathrm{Ti}$ & 0.027 & 0 & 0 & 0.008 & 0.037 \\
\hline $\mathrm{Fe}^{2+}$ & 3.803 & 4.323 & 4.609 & 3.378 & 2.979 \\
\hline $\mathrm{Mn}$ & 0.093 & 0.094 & 0.096 & 0.083 & 0.067 \\
\hline $\mathrm{Mg}$ & 5.553 & 5.119 & 4.780 & 6.156 & 6.084 \\
\hline $\mathrm{Ca}$ & 0.009 & 0.022 & 0.041 & 0.022 & 0.091 \\
\hline $\mathrm{Na}$ & 0.008 & 0.024 & 0.008 & 0.012 & 0.023 \\
\hline K & 0 & 0.016 & 0.011 & 0.003 & 0.023 \\
\hline Total & 19.969 & 19.939 & 19.908 & 19.945 & 19.675 \\
\hline
\end{tabular}

Notes: 1 = D794-8, accompanying with pumpellyite; 2 = D794-8, replacement of mafic microphenocryst; $3=\mathrm{D} 794-7$, replacement of plagioclase accompanying with pumpellyite; 4 = pore filling; 5 = replacement of pumice fragment. phosed andesitic volcanic rock dated as Oligocene, and the other was the metamorphosed volcanic breccia described here. The $\mathrm{Ti}, \mathrm{Zr}$, and $\mathrm{Y}$ contents of these rocks were analyzed with X-ray fluorescence (Toshiba AFC-202F) using the powder disc method (Terashima, 1977). The results are shown in Table 5 and plotted on the Ti-Zr-Y diagram in Figure 7, which most easily discriminates tectonic settings of magma generation. Samples of the two rock types plot in separate fields, that is, the nonmetamorphosed Oligocene andesites plot within the calc-alkali basalt field and volcanic breccia in the ocean-floor basalt field. The separation is mainly caused by the different $\mathrm{Zr}$ contents of the rocks. Although we should not draw a hasty conclusion that the origin of the metavolcanic rocks is oceanic in nature because of the calc-alkali basalt field to which these rocks are plotted, the activity producing the original volcanic rocks may well be different from that of nonmetamorphosed volcanic rocks and before the Oligocene. Before the Parece Vela Basin rifting, a nascent island arc would have been formed along the eastern edge of the West Philippine Basin by subduction of the Pacific Plate that began about $42 \mathrm{Ma}$. The metamorphosed volcanic rocks of the Ohmachi Seamount are considered to be the basement of the nascent arc.

\section{Timing of the Metamorphism}

The metamorphosed crystal-lithic tuff described above is considered to have deposited in the Sumisu Rift before rifting. Although some heat flow values of the Sumisu Rift floor at present (Yamazaki, 1988) are sufficiently high to form prehnite-pumpellyite facies mineral assemblages, pumpellyite and epidote occur only in the lowermost part of Site 791 and have not been found in the syn-rift basalt and intercalated lithic tuff from the adjacent upper part of the core. The variable heat flow values measured over the Sumisu Rift suggest the existence of hydrothermal circulation (Yamazaki, 1988). If pumpellyite and epidote have formed in the crystal-lithic tuff in the lowermost part of the core as a result of present-day hydrothermal alteration, then the syn-rift basalt and intercalated tuff should also have these secondary minerals. Therefore, we conclude that prehnitepumpellyite facies metamorphism affected the rocks before the present-day hydrothermal circulation related to the present rifting under the Sumisu Rift floor began. 
Table 4. Representative chemical compositions of prehnite from the Ohmachi Seamount.

\begin{tabular}{lcc}
\hline & \multicolumn{2}{c}{ Ohmachi Seamount } \\
\hline & 1 & 2 \\
\hline & $\begin{array}{c}\text { Amygdule } \\
\text { filling }\end{array}$ & $\begin{array}{c}\text { Amygdule } \\
\text { filling }\end{array}$ \\
\hline & & \\
$\mathrm{SiO}_{2}$ & 43.40 & 43.48 \\
$\mathrm{TiO}_{2}$ & 0.08 & 0 \\
$\mathrm{Al}_{2} \mathrm{O}_{3}$ & 21.02 & 20.57 \\
$\mathrm{FeO}$ & 4.10 & 5.13 \\
$\mathrm{MnO}$ & 0.33 & 0.22 \\
$\mathrm{MgO}$ & 0 & 0 \\
$\mathrm{CaO}$ & 26.12 & 26.04 \\
$\mathrm{Na} 2 \mathrm{O}$ & 0.02 & 0.04 \\
$\mathrm{~K} 2 \mathrm{O}$ & 0.01 & 0 \\
$\mathrm{Total}$ & 95.08 & 95.48 \\
& & \\
$\mathrm{Si}$ & 3.064 & 3.071 \\
$\mathrm{AlIV}$ & 0 & 0 \\
$\mathrm{AlVI}$ & 1.749 & 1.713 \\
$\mathrm{Ti}$ & 0.004 & 0 \\
$\mathrm{Fe}$ & 0.242 & 0.303 \\
$\mathrm{Mn}$ & 0.020 & 0.013 \\
$\mathrm{Mg}$ & 0 & 0 \\
$\mathrm{Ca}$ & 1.976 & 1.971 \\
$\mathrm{Na}$ & 0.003 & 0.005 \\
$\mathrm{~K}$ & 0.001 & 0 \\
$\mathrm{Total}$ & 7.059 & 7.076 \\
\hline Notes: 1 aand $2=\mathrm{D}$ & & \\
with quartz. & & \\
& & \\
& &
\end{tabular}

Several other theories have been raised on the timing of metamorphism of the Ohmachi Seamount rocks. One possible heat source for the metamorphism can be related to the rifting of the ocean floor or arc. The oldest theory is concerned with ocean-floor metamorphism during the West Philippine Basin opening. The second oldest possibility is the rifting of the nascent arc mentioned above. The third is that hydrothermal metamorphism accompanied faulting of the Ohmachi Seamount after the development of the Parece Vela Basin.

Although it is difficult to assume a heat source in the forearc region, fossil hydrothermal manganese oxides are often dredged from forearc seamounts in the northern Izu-Bonin Arc area (Yuasa and Yokota, 1982). However, such manganese oxides have not been obtained from the Ohmachi Seamount, and the dredged volcanic and sedimentary rock samples without the metamorphic rocks described here are not affected by hydrothermal alteration. From these facts, the third possibility is improbable.

For the other two possibilities, a heat source is related to thermal culmination at the time of rifting of the pre-existing basement. The difference between the two depends on whether the pre-existing basement originated from the West Philippine Basin floor or from the basement under the nascent arc; that is, whether or not the basement is derived from oceanic crust or nascent-island-arc crust. As mentioned above, Ti-Zr-Y concentrations of the metavolcanic rocks do not clearly discriminate between an oceanic- or island-arc tectonic setting, although in either setting, metamorphism must have occurred before the development of the present arc. Considering the history of heating related to the rifting of the ocean floor or arc, highest temperatures would be expected to have been attained at the beginning of rifting. The above-described metamorphic rocks from two sites of the Izu-Bonin Arc indicate that the highest grade of metamorphism that affected each region was of prehnite-pumpellyite facies grade. Therefore, even at the rifting stage, the geothermal gradient of the backarc or intra-arc spreading area was not as high as that normally attained during mid-oceanic-ridge spreading (Maruyama and Liou, 1988; Maruyama et al., 1989).

\section{CONCLUSIONS}

Pumpellyite-bearing metamorphic rocks were drilled at Site 791 in the Sumisu Rift and dredged from the Ohmachi Seamount on the Izu-Bonin Arc, western Pacific. Mineral chemistry and paragenetic relations among pumpellyite, epidote, chlorite, and prehnite indicate that the metamorphic conditions were those of prehnite-pumpellyite facies grade. As these rocks are intercalated with or overlain by syn-rift basalt (the Sumisu Rift) or nonmetamorphosed calc-alkali andesites (the Ohmachi Seamount), we suggest that the rocks constituted part of the island-arc basement before rifting occurred. The metamorphism took place in the pre-rifting stage of the intraoceanic arc. At the backarc rifting stage, the geothermal gradient of the area was not as high as that of the spreading mid-oceanic ridge.

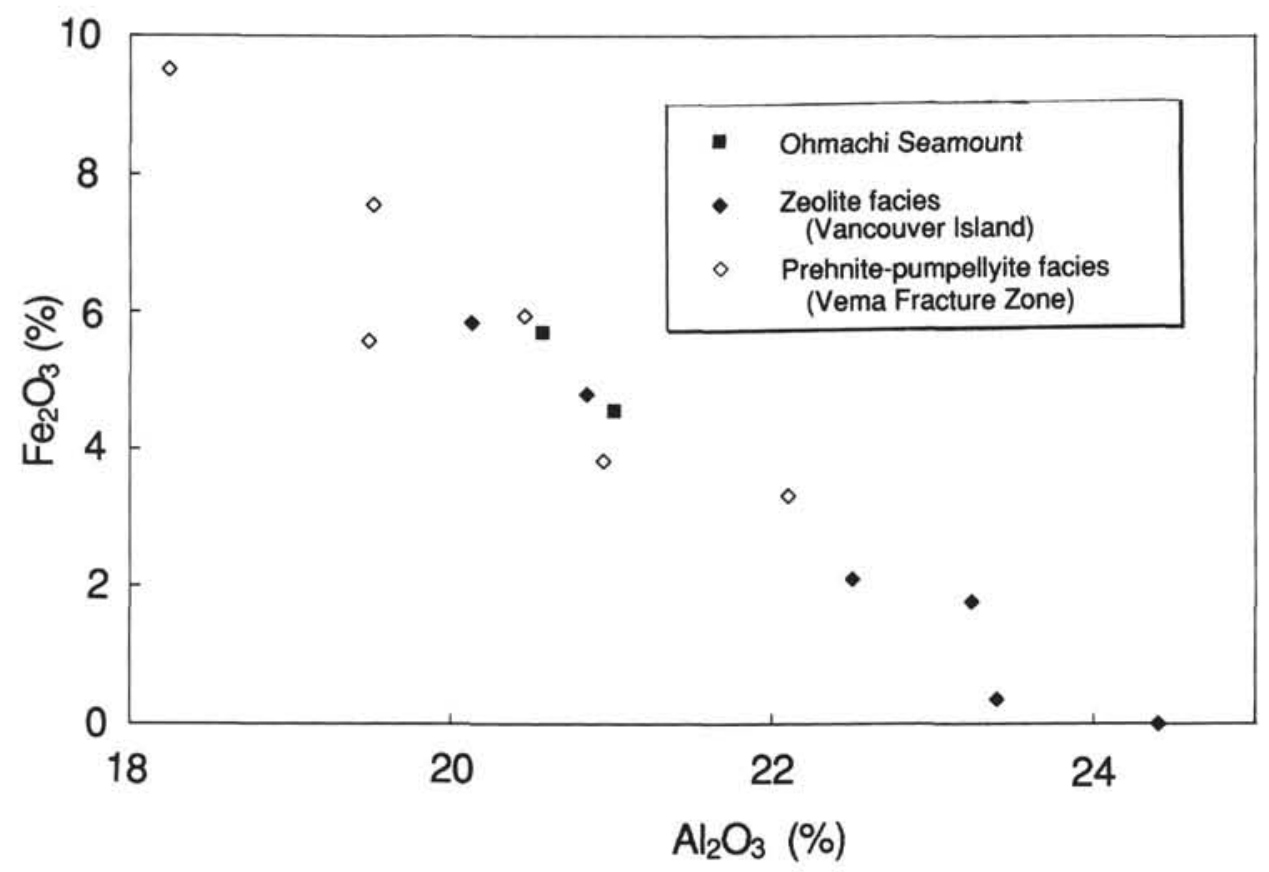

Figure 6. $\mathrm{Fe}_{2} \mathrm{O}_{3}$ vs. $\mathrm{Al}_{2} \mathrm{O}_{3}$ diagram of prehnite from the Ohmachi Seamount compared with data from other metamorphic areas. References to chemical compositions are as follows: Vancouver Island (Cho et al., 1986) and Vema Fracture Zone (Mevel, 1981). 
Table 5. Trace element contents of metamorphic and nonmetamorphic volcanic rocks from the Ohmachi Seamount.

\begin{tabular}{|c|c|c|c|c|c|c|c|c|c|}
\hline No. & D794-1 & D794-7 & D794-8 & D731-51 & D731-56 & D731-59 & D731-60 & D731-61 & D731-4 \\
\hline Rock & $\mathrm{m}$ & m & $\mathrm{m}$ & a & a & a & a & a & a \\
\hline $\begin{array}{l}\mathrm{TiO}_{2}(\%) \\
\mathrm{Y}(\mathrm{ppm}) \\
\mathrm{Zr}(\mathrm{ppm})\end{array}$ & $\begin{array}{l}0.85 \\
20 \\
60\end{array}$ & $\begin{array}{l}0.66 \\
20 \\
64\end{array}$ & $\begin{array}{l}0.59 \\
17 \\
49\end{array}$ & $\begin{array}{l}0.73 \\
31 \\
97\end{array}$ & $\begin{array}{l}0.54 \\
23 \\
102\end{array}$ & $\begin{array}{l}0.55 \\
29 \\
118\end{array}$ & $\begin{array}{l}0.61 \\
25 \\
99\end{array}$ & $\begin{array}{l}0.71 \\
24 \\
89\end{array}$ & $\begin{array}{l}0.72 * \\
31 \\
98\end{array}$ \\
\hline
\end{tabular}

Notes: $\mathrm{TiO}_{2}$ contents are shown in weight percent and others are in ppm. ${ }^{*}=$ wet analysis, others are analyzed by XRF. $\mathrm{m}=$ metamorphic and $\mathrm{a}=$ nonmetamorphic andesitic rocks.

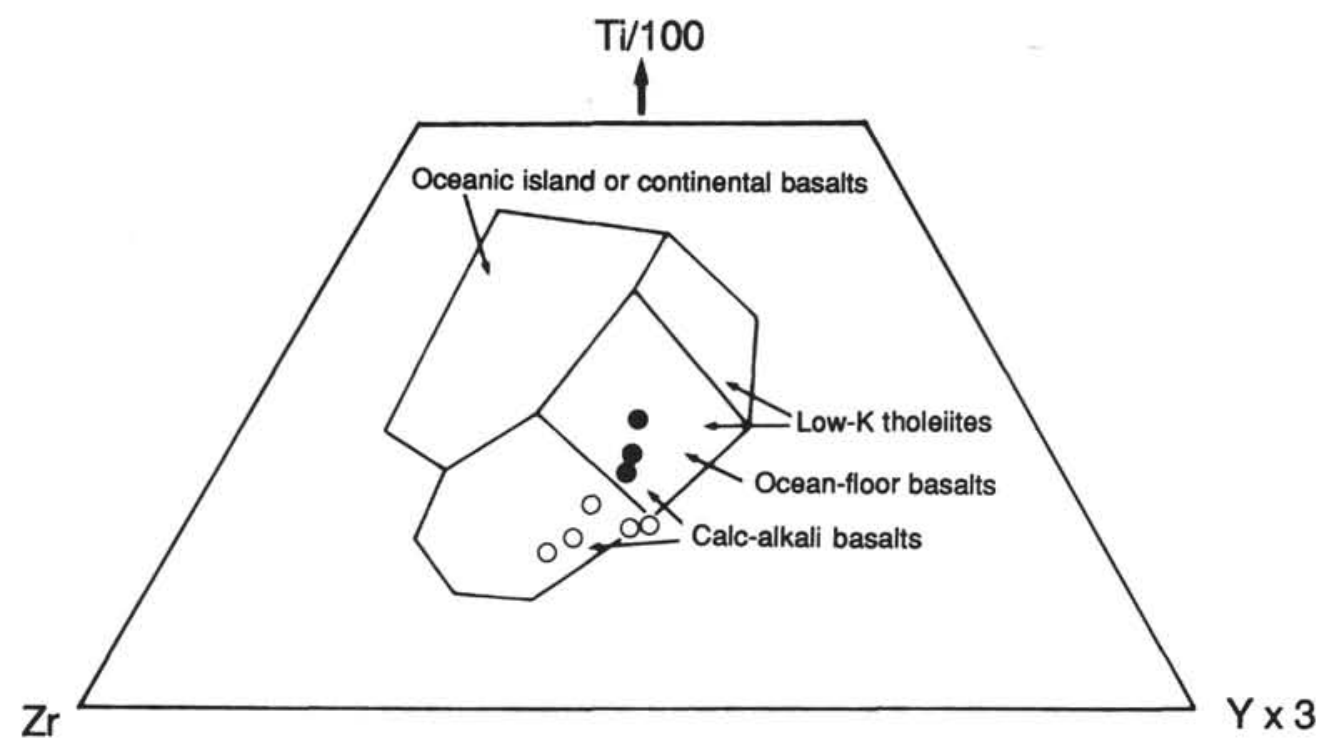

Figure 7. Ti, Zr, and Y discrimination diagram (Pearce and Cann, 1973) for nonmetamorphosed andesite (open circles) and metamorphosed volcanic rocks (solid circles) from the Ohmachi Seamount.

\section{ACKNOWLEDGMENTS}

We would like to thank Dr. Y. Kawachi, University of Otago, and Dr. H. Ishizuka, Kochi University, for critical reading of the manuscript and helpful suggestions. Thanks are given to Messrs. H. Goto, H. Kanaya, H. Makimoto, and K. Okumura, Geological Survey of Japan, for their assistance during the XRF and EPMA analyses.

\section{REFERENCES}

Bence, A. E., and Albee, A. L., 1968. Empirical correction factors for the electron microanalysis of silicates and oxides. J. Geol., 76:382-403.

Cho, M., Liou, J. G., and Maruyama, S., 1986. Transition from the zeolite to prehnite-pumpellyite facies in the Karmutsen metabasites, Vancouver Island, British Columbia. J. Petrol., 27:467-494.

Coombs, D. S., Nakamura, Y., and Vuagnat, M., 1976. Pumpellyite-actinolite facies schists of the Taveyanne Formation near Loeche, Valais, Switzerland. J. Petrol., 17:440-471.

Fujioka, K., 1988. A possible nascent rift in northern Izu-Ogasawara Arc. Tectonics of Eastern Asia and Western Pacific Continental Margin. 1988 DELPTokyo Int. Symp. and Sixth Japan-U.S.S.R. Geotectonic Symp., No. 25. (Abstract)

Honza, E., Tamaki, K., Yuasa, M., Tanahashi, M., and Nishimura, A., 1982. Geological Map of the Northern Ogasawara Arc, Scale 1:1,000,000. Mar. Geol. Map Ser., No. 17, Geol. Surv. Jpn.

Ikeda, Y., and Yuasa, M., 1989. Volcanism in nascent back-arc basins behind the Shichito Ridge and adjacent areas in the Izu-Ogasawara arc, northwest Pacific: evidence for mixing between E-type MORB and island arc magmas at the initiation of back-arc rifting. Contrib. Mineral. Petrol., 101:377-393.
Ishizuka, H., 1991. Pumpellyite from zeolite facies metabasites of the Horokanai ophiolite in the Kamuikotan zone, Hokkaido, Japan. Contrib. Mineral. Petrol., 107:1-7.

Kawachi, Y., 1975. Pumpellyite-actinolite and contiguous facies metamorphism in part of Upper Wakatipu district, South Island, New Zealand. N.Z. J. Geol. Geophys., 18:401-441.

Lucchetti, G., Cabella, R., and Cortesogno, L., 1990. Pumpellyites and coexisting minerals in different low-grade metamorphic facies of Ligria, Italy. J. Metamorph. Geol., 8:539-550.

Maruyama, S., and Liou, J. G., 1988. Ocean-floor metamorphism at different tectonic settings: a review on the DSDP drilling project. Eos, 69:1403.

Maruyama, S., Terabayashi, M., and Fujioka, K., 1989. Origin and emplacement of ophiolite: a review. J. Geogr., 98:319-349.

Mevel, C., 1981. Occurrence of pumpellyite in hydrothermally altered basalts from the Vema Fracture Zone (Mid-Atlantic Ridge). Contrib. Mineral. Petrol., 76:386-393.

Mrozowski, C. L., and Hayes, D. E., 1979. The evolution of the Parece Vela Basin, eastern Philippine Sea. Earth Planet. Sci. Lett., 46:49-67.

Murakami, F., 1988. Structural framework of the Sumisu Rift, Izu-Ogasawara Arc. Bull. Geol. Surv. Jpn., 39:1-21.

Okumura, K., and Soya, T., 1976. Quantitative analysis of silicate minerals by automated electron probe microanalyser. J. Mineral. Soc. Jpn., 12:116-124.

Pearce, J. A., and Cann, J. R., 1973. Tectonic setting of basic volcanic rocks determined using trace element analyses. Earth Planet. Sci. Lett., 19:290-300.

Shih, T. C., 1980. Magnetic lineations in the Shikoku Basin. In Klein, G. de V., Kobayashi, K., et al., Init. Rept. DSDP, 58: Washington (U.S. Govt. Printing Office), 783-788.

Shipboard Scientific Party, 1990. Sites 790/791. In Taylor, B., Fujioka, K., et al., Proc. ODP, Init. Repts., 126: College Station, TX (Ocean Drilling Program), 127-220. 
Tamaki, K., Inoue, E., Yuasa, M., Tanahashi, M., and Honza, E., 1981. On the possibility of active back-arc spreading of Ogasawara Arc. Earth Monthly (Chikyu), 3:421-431.

Terashima, S., 1977. X-ray fluorescence determination of chromium, gallium, niobium, lead, rubidium, strontium, yttrium, zinc and zirconium in rocks. Bull. Geol. Surv. Jpn., 28:393-399.

Yamazaki, T., 1988. Heat flow in the Sumisu Rift, Izu-Ogasawara (Bonin) Arc. Bull. Geol. Surv. Jpn., 39:63-70.

Yuasa, M., 1985. Sofugan Tectonic Line, a new tectonic boundary separating northern and southern parts of the Ogasawara (Bonin) Arc, northwest Pacific. In Nasu, N., Kobayashi, K., Uyeda, S., Kushiro, I., and Kagami, H. (Eds.), Formation of Active Ocean Margins: Tokyo (Terra Sci. Pub.), 483-496.
Yuasa, M., Uchiumi, S., Nishimura, A., and Shibata, K., 1988. K-Ar age of a forearc seamount adjacent to the volcanic front of the Izu-Ogasawara Arc. Bull. Volcanol. Soc. Jpn., 33:352-353. (Abstract)

Yuasa, M., and Yokota, S., 1982. Hydrothermal manganese and ferromanganese concretions from seafloor of the Ogasawara Arc-Trench region, northwestern Pacific. UN ESCAP CCOPTech. Bull., 15:51-64.

Date of initial receipt: 26 December 1990

Date of acceptance: 10 June 1991

Ms 126B-127 